\title{
Effect of Sodium Lauryl Sulfate-Fumaric Acid Coupled Addition on the In Vitro Rumen Fermentation with Special Regard to Methanogenesis
}

\author{
M. A. Abdl-Rahman, ${ }^{1}$ F. A. R. Sawiress, ${ }^{1}$ and A. M. Abd El-Aty ${ }^{2}$ \\ ${ }^{1}$ Department of Physiology, Faculty of Veterinary Medicine, Cairo University, Giza 12211, Egypt \\ ${ }^{2}$ Department of Pharmacology, Faculty of Veterinary Medicine, Cairo University, Giza 12211, Egypt \\ Correspondence should be addressed to M. A. Abdl-Rahman, mahmod.abdelhafez@gmail.com and \\ A. M. Abd El-Aty, abdelaty44@hotmail.com
}

Received 30 June 2009; Revised 12 August 2009; Accepted 25 September 2009

Academic Editor: Maria Laura Bacci

Copyright ( 2010 M. A. Abdl-Rahman et al. This is an open access article distributed under the Creative Commons Attribution License, which permits unrestricted use, distribution, and reproduction in any medium, provided the original work is properly cited.

\begin{abstract}
The aim of the current study was to evaluate the effect of sodium lauryl sulfate-fumaric acid coupled addition on in vitro methangenesis and rumen fermentation. Evaluation was carried out using in vitro gas production technique. Ruminal contents were collected from five steers immediately after slaughtering and used for preparation of inoculums of mixed rumen microorganisms. Rumen fluid was then mixed with the basal diet of steers and used to generate four treatments, negative control (no additives), sodium lauryl sulfate (SLS) treated, fumaric acid treated, and SLS-fumaric acid coupled addition treated. The results revealed that, relative to control, efficiency in reduction of methanogenesis was as follows: coupled addition > SLS-addition > fumaric acid addition. Both SLS-addition and SLS-fumaric acid coupled addition demonstrated a decremental effect on ammonia nitrogen $\left(\mathrm{NH}_{3}-\mathrm{N}\right)$, total short chain volatile fatty acids (SCVFAs) concentrations and the amount of substrate degraded, and an increment effect on microbial mass and microbial yield $\left(\mathrm{Y}_{\text {ATP }}\right)$. Nevertheless, fumaric acid did not alter any of the previously mentioned parameters but induced a decremental effect on $\mathrm{NH}_{3}-\mathrm{N}$. Furthermore, both fumaric acid and SLS-fumaric acid coupled addition increased propionate at the expense of acetate and butyrate, while, defaunation increased acetate at the expense of propionate and butyrate. The $\mathrm{pH}$ value was decreased by all treatments relative to control, while, cellulase activity did not differ by different treatments. The current study can be promising strategies for suppressing ruminal methane emissions and improving ruminants feed efficiency.
\end{abstract}

\section{Introduction}

Ruminal methanogenesis represents a loss of feed energy for ruminants and a significant source of global warming and pollution into our atmosphere. Energy lost as enteric methane from mature cattle ranges from $2-12 \%$ of gross energy intake [1] depending on diet composition [2-4]. Inhibition of methanogenesis may therefore have significant economical and environmental benefits [5].

Many feed additives have been developed to improve the efficiency of nutrient use by decreasing the total amount of methane production, among which ionophore antibiotics have been very successful [6]. However, the chance to find antibiotics residues in milk and meat and their effects on human health suggests to look closer to decrease their use and seek for safer alternatives.

Generally, methane is produced by two types of methanogens, the slow growing methanogens (generation time 130 hours) that produces methane from acetic acid, and fast growing methanogens (generation time 4-12 hours) that reduce $\mathrm{CO}_{2}$ with $\mathrm{H}_{2}$. In the rumen, methanogenesis occurs mostly by the later pathway as ruminal retention times are too short to permit establishment of the slow growing species [7].

Newbold et al. [8] had described an intimate metabolic correlation between methanogenic bacteria and ciliate 
protozoa. Protozoa consume oxygen [9] and oxygen levels were found to increase transiently in defaunated animals that adversely affect methangenic archea [10].

Theoretically, methanogenesis can be reduced by decreasing $\mathrm{H}_{2}$ production or by increasing $\mathrm{H}_{2}$ utilization. However, direct inhibition of reactions that form $\mathrm{H}_{2}$ may depress fermentation in microorganisms producing $\mathrm{H}_{2}$, including the main cellulolytic bacteria, because $\mathrm{H}_{2}$ production is a mean for the disposal of electrons liberated by the oxidation of energy-yielding substrates [11]. On the other hand, increasing $\mathrm{H}_{2}$ utilization by organisms other than methanogens requires addition of an appropriate electron acceptor and an efficient type of rumen bacteria that can perfectly utilize such acceptor in production of a more beneficial product, namely, propionate. These include fumarate utilizing bacteria (Bacteroides ruminicola, Bacteroides succinogens and Selenomonus ruminantium) [12-14].

Propionate precursors (malate, fumarate, and succinate) were found to be a desirable alternative route for hydrogen disposal leading to reduction of methanogenesis and enhancement of propionate production [12-14]. However the affinity of fumarate reducing bacteria to hydrogen was lower than the affinity of methanogens, so methanogenic microorganisms can outcompete fumarate reducing bacteria at low hydrogen concentration normally present in the rumen [12].

On the contrary, defaunating agents (e.g., Sodium lauryl sulphate) were found to strongly inhibit methanogenesis [15]. However accumulation of hydrogen would prevent further degradation of organic matter [16].

Could Lauryl sulfate-fumaric acid coupled addition overcome microbiological constraints of single feed additivesupplementation and achieve sustained inhibition of rumen methanogenesis? This was the aim of this investigation.

\section{Materials and Methods}

This work was carried out in the Department of Physiology, Faculty of Veterinary Medicine, Cairo University, Egypt. The experimental protocol was approved by the Institutional Animal Care and Use Committee of the Faculty of Veterinary Medicine, Cairo University.

2.1. Collection of Rumen Contents. Ruminal contents used to prepare the treatment systems were collected from the rumen of five slaughtered steers and immediately transferred to the laboratory in a prewarmed thermos flask. Collected ruminal fluids were handled as described by Callaway and Martin (1997) [17]. Ruminal fluids were strained through four layers of cheesecloth into a separating flask previously gassed with oxygen-free $\mathrm{CO}_{2}$ and brought immediately to the laboratory. The samples were then incubated under anaerobic conditions at $39^{\circ} \mathrm{C}$ for up to 60 minutes to allow small feed particles to buoy up and the microbial fractions to sediment at the bottom. Small feed particles that had floated to the surface were removed, and the particle-free fluids were mixed with the buffer solution of Goering and
TABLE 1: Composition and chemical analysis of the used basal diet.

\begin{tabular}{lc}
\hline Ingredients & $\%$ \\
\hline Barely, grain & 39.56 \\
Berseem hay & 40.00 \\
Wheat straw & 20.14 \\
Vitamin and mineral premix & 0.30 \\
\hline Chemical analysis & \% of dry matter \\
\hline Crude fibers & 31 \\
Crude proteins & 13 \\
Ether extract & 2.8 \\
Nitrogen free extract & 32.5 \\
total ash & 10.6 \\
\hline
\end{tabular}

Van Soest [18] in the proportion $1: 2(\mathrm{v} / \mathrm{v})$, flushed with oxygen-free $\mathrm{CO}_{2}$, and used as inoculums of mixed rumen microorganisms.

\subsection{Preparation of Treatment Systems and In Vitro Fermenta-} tion. The method used for in vitro fermentation was based on the technique described earlier by Menke et al. [19], and slightly modified by Ngamsaeng and Wanapat [20]. Two- hundred milligrams of feed sample (composition and chemical analysis are shown in Table 1) were weighed into $60 \mathrm{~mL}$ calibrated plastic syringes with pistons lubricated with vaseline. Approximately $30 \mathrm{~mL}$ of buffered rumen fluid was dispensed into the syringes and the following treatment systems were then prepared for each sample in a duplicate syringes per treatment: negative control (no additives), sodium lauryl sulfate treated $(0.01 \mathrm{mg} / \mathrm{mL})$, fumaric acid treated $(0.5 \mathrm{mg} / \mathrm{mL})$, and sodium lauryl sulfate-fumaric acid coupled treated $(0.01$ and $0.5 \mathrm{mg} / \mathrm{mL}$ of each), respectively. After gentle shaking, syringes were incubated at $39^{\circ} \mathrm{C}$ and the volume of gas produced was recorded at 24 hours post incubation. For each sample, duplicate syringes per treatment were incubated to be used for measurement of in vitro true degradability with concomitant microbial mass generated.

\subsection{Analysis}

2.3.1. Determination of $p H$. After termination of incubation, the fluid samples were drawn into plastic bottles and $\mathrm{pH}$ was immediately determined using $\mathrm{pH}$ meter.

2.3.2. Determination of Total VFAs Concentrations and Individual VFAs Proportions. For determination of total VFAs concentrations and individual VFAs proportions $1 \mathrm{~mL}$ of $25 \%$ meta-phosphoric acid was added to $5 \mathrm{~mL}$ of fermentation fluids, centrifuged $(7000 \times \mathrm{g}$ for 10 minute) and supernatants were stored at $-20^{\circ} \mathrm{C}$ until analyzed. Total VFAs concentrations were measured by steam distillation [21] and molar proportions of VFAs were analyzed using High Performance Liquid Chromatography (HPLC; Model Water 600; UV detector, Millipore Crop.) according to the method of Mathew et al. [22]. 
2.3.3. Determination of Ammonia Nitrogen Concentration. Two mL sample of fermented fluid was acidified with $2 \mathrm{~mL}$ of $0.2 \mathrm{~N} \mathrm{HCl}$ and frozen. Samples were centrifuged at $5000 \times \mathrm{g}$ for 20 minute, and the supernatant was analyzed by spectrophotometry [23] for ammonia $\mathrm{N}$.

2.3.4. Calculation of Fermentative $\mathrm{CO}_{2}$ and $\mathrm{CH}_{4}$. Fermentative $\mathrm{CO}_{2}$ and $\mathrm{CH}_{4}$ in the buffered rumen fluid were estimated by the equations of Wolin [24], which have been validated recently by Blümmel et al. [25] as following:

$$
\text { Fermentative } \mathrm{CO}_{2}=\mathrm{A} / 2+\mathrm{P} / 4+1.5 \mathrm{~B}
$$

where $\mathrm{A}, \mathrm{P}$ and $\mathrm{B}$ are moles of acetate, propionate, and butyrate, respectively.

$$
\text { Fermentative } \mathrm{CH}_{4}=(\mathrm{A}+2 \mathrm{~B})-\mathrm{CO}_{2}
$$

where $\mathrm{A}$ and $\mathrm{B}$ are moles of acetate and butyrate respectively and $\mathrm{CO}_{2}$ is moles of $\mathrm{CO}_{2}$ calculated from previous equation.

2.3.5. Measurement of Extracellular Cellulase Activity. Supernatant from each fermentation fluid sample was separated by centrifugation at $3000 \mathrm{rpm}$ for 20 minute. Half $\mathrm{mL}$ of the supernatant (crude enzyme solution) was mixed with $0.5 \mathrm{~mL}$ of $1 \%$ carboxymethyl cellulose (CMC) solution in $0.05 \mathrm{M}$ sodium citrate buffer. The reaction proceeded for 1 hour at $55^{\circ} \mathrm{C}$ without shaking, and then stopped by boiling for 5 minute. Boiled samples were centrifuged at $7000 \mathrm{rpm}$ for 5 minute, and reducing sugars produced in the supernatants was measured colorimetrically [26]. One unit of enzyme activity was defined as the amount of enzyme that produced $1 \mathrm{mmoL}$ of glucose equivalent of reducing sugar per minute.

2.3.6. Measurement of In Vitro True Degradability with Concomitant Microbial Mass Generated. In vitro true degradability was determined according to the procedures of Blümmel et al. [27]. The remaining contents of the separate syringes were drained into beakers and syringes were thoroughly washed with neutral detergent solution (NDS). The contents were digested with NDS for one hour to solubilize microbes and obtain only the undegraded feed. The contents were then filtered, dried at $130^{\circ} \mathrm{C}$ for 2 hour, and weighed. True degradability was then calculated as the weight of substrate incubated minus the weight of the residue after NDS treatment. The microbial mass generated by termination of incubation could then be estimated according to Grings et al. [28] as follows:

$$
\begin{aligned}
\text { microbial mass }(\mathrm{mg})= & \text { mg substrate truly degraded } \\
& -(\mathrm{mL} \text { gas volume } \times 2.2)
\end{aligned}
$$

where 2.2 is a stoichiometrical factor.

The microbial yield ( $\mathrm{Y}_{\mathrm{ATP}}$ ) was then calculated as the mg microbial mass produced per mmole ATP generated in fermentation of carbohydrates to VFAs. The moles of ATP generated per mole of SCVFAs are 2 for acetate, 3 for propionate, 3 for butyrate, and 1 for methane [29].
2.4. Statistical Analysis. Data were analyzed by one way analysis of variance (ANOVA) test according to Snedecor and Cochran [30]. Treatment means were compared by the least significance difference (LSD) at 5\% level of probability.

\section{Results}

Table 2 identifies that total gas production was decreased by defaunation and by SLS-fumaric acid coupled addition, but it was not affected by fumaric acid addition. However, the decremental effect induced by coupled addition surpassed the decremental effect of defaunation $(32.7 \%$ versus $18.3 \%)$. Furthermore, the means of different treatment systems denote that SLS-fumaric acid coupled addition had a tremendous damping effect on $\mathrm{CO}_{2}$ and $\mathrm{CH}_{4}$ production $\left(40.1 \%\right.$ and $43.07 \%$, resp.). In contrast, $\mathrm{CO}_{2}$ and $\mathrm{CH}_{4}$ were moderately reduced by defaunation $(21.6 \%$ and $17.7 \%$, resp.). However, fumaric acid addition did not alter the output of $\mathrm{CO}_{2}$ but induced a slight reduction in $\mathrm{CH}_{4}(11 \%)$.

Data presented in Table 3 reveals that, the $\mathrm{pH}$ value of the fermentation fluid was decreased by all treatments relative to control, however decremental effect of both fumaric acid addition and SLS-fumaric acid coupled addition exceed that recorded by defaunation. Meanwhile, ammonia nitrogen concentration and total SCVFAs were decreased by both defaunation and SLS-fumaric acid coupled addition; however, the decremental effect induced by coupled addition outdid that induced by defaunation (57\% versus $47.3 \%$ for ammonia nitrogen and $36.3 \%$ versus $20.4 \%$ for total SCVFAs). In contrast, addition of fumaric acid did not alter the concentration of total SCVFAs but induced a decremental effect on ammonia nitrogen concentration. Furthermore, the overall mean of VFAs molar proportions reveals that both fumaric acid addition and SLS-fumaric acid coupled addition were associated with increased propionates at the expense of acetate and butyrates and therefore, a lowered $\mathrm{A} / \mathrm{P}$ ratio was recorded for both treatments. Conversely, defaunation was associated with increased acetate at the expense of propionates and butyrates so, recorded a higher $\mathrm{A} / \mathrm{P}$ ratio.

It is evident from Table 4 that the extracellular cellulase activity within the fermentation fluid did not alter by different treatment systems relative to control. Nevertheless, the amount of substrate degraded was reduced by both defaunation and SLS-fumaric acid coupled addition, while it was not affected by the addition of fumaric acid. In contrast, microbial mass generated during fermentation was increased by both defaunation and SLS-fumaric acid coupled addition while, it also was not affected by addition of fumaric acid. Additionally, microbial yield/mmole ATP generated during fermentation $\left(\mathrm{Y}_{\mathrm{ATP}}\right)$ was increased by both defaunation and SLS-fumaric acid coupled addition, however, the increment effect of SLS-fumaric acid coupled addition was overwhelming (84\% versus $36.5 \%$ achieved by defaunation). Nevertheless, fumaric acid addition did not alter $\mathrm{Y}_{\mathrm{ATP}}$. 
TABLE 2: Effect of treatment systems on gas production and output of $\mathrm{CO}_{2}$ and $\mathrm{CH}_{4}$ by mixed rumen microorganisms after 24 hours.

\begin{tabular}{lllll}
\hline Parameter & $\begin{array}{l}\text { Control (no } \\
\text { additives) }\end{array}$ & $\begin{array}{l}\text { SLS-addition } \\
\text { (defaunation) }\end{array}$ & $\begin{array}{l}\text { Fumaric acid } \\
\text { addition }\end{array}$ & $\begin{array}{l}\text { SLS-Fumaric } \\
\text { acid coupled } \\
\text { addition }\end{array}$ \\
\hline Gas volume $(\mathrm{mL})$ & $25.10^{(\mathrm{a})} \pm 0.83$ & $20.50^{(\mathrm{ab})} \pm 0.42$ & $25.20^{(\mathrm{b})} \pm 1.24$ & $16.90^{(\mathrm{ab})} \pm 0.43$ \\
$\mathrm{CO}_{2}(\mu \mathrm{moL})$ & $318.4^{(\mathrm{a})} \pm 11.70$ & $249.6^{(\mathrm{ab})} \pm 5.88$ & $301.2^{(\mathrm{b})} \pm 17.13$ & $190.6^{(\mathrm{ab})} \pm 6.56$ \\
$\mathrm{CH}_{4}(\mu \mathrm{moL})$ & $144.4^{(\mathrm{a})} \pm 5.36$ & $118.8^{(\mathrm{ab})} \pm 3.65$ & $128.4^{(\mathrm{ac})} \pm 8.64$ & $82.2^{(\mathrm{abc})} \pm 3.09$ \\
\hline
\end{tabular}

Data presented as means $\pm \mathrm{SE}, N=5$

Values having the same letter in the same raw are significantly different at $P<0.05$.

TABLE 3: Effect of treatment systems on fermentation pattern by mixed rumen microorganisms after 24 hours in vitro incubation.

\begin{tabular}{|c|c|c|c|c|c|}
\hline Parameter & $\begin{array}{l}\text { Control (no } \\
\text { additives) }\end{array}$ & $\begin{array}{l}\text { SLS- addition } \\
\text { (defaunation) }\end{array}$ & $\begin{array}{l}\text { Fumaric acid } \\
\text { addition }\end{array}$ & $\begin{array}{l}\text { SLS-Fumaric acid } \\
\text { coupled addition }\end{array}$ & L.S.D. \\
\hline $\mathrm{pH}$ value & $6.95^{(\mathrm{a})} \pm 0.0051$ & $6.88^{(\mathrm{ab})} \pm 0.0140$ & $6.79^{(\mathrm{ab})} \pm 0.0037$ & $6.76^{(\mathrm{ac})} \pm 0.0160$ & 0.0332 \\
\hline Ammonia N. conc. (mg/dL) & $21.44^{(\mathrm{a})} \pm 0.18$ & $11.29^{(\mathrm{ab})} \pm 0.72$ & $10.15^{(\mathrm{ac})} \pm 0.48$ & $9.20^{(\mathrm{ab})} \pm 0.10$ & 1.333 \\
\hline Total SCVFAs conc. $(\mu \mathrm{moL})$ & $542.4^{(\mathrm{a})} \pm 19.86$ & $431.6^{(\mathrm{ab})} \pm 10.05$ & $544.6^{(\mathrm{b})} \pm 29.96$ & $345.4^{(\mathrm{ab})} \pm 10.26$ & 58.02 \\
\hline Acetic acid (moL/100 moL) & $51.44^{(\mathrm{a})} \pm 0.05$ & $54.08^{(\mathrm{ab})} \pm 0.36$ & $49.93^{(\mathrm{abc})} \pm 0.36$ & $50.0^{(\mathrm{abd})} \pm 0.48$ & 1.05 \\
\hline Propionic acid (moL/100 moL) & $30.49^{(\mathrm{a})} \pm 0.017$ & $27.75^{(\mathrm{ab})} \pm 0.006$ & $34.10^{(\mathrm{abc})} \pm 0.016$ & $33.84^{(\mathrm{abd})} \pm 0.160$ & 0.244 \\
\hline Butyric acid (moL/100 moL) & $16.78^{(\mathrm{a})} \pm 0.022$ & $16.36^{(\mathrm{ab})} \pm 0.013$ & $14.55^{(\mathrm{abc})} \pm 0.016$ & $14.73^{(\mathrm{abc})} \pm 0.017$ & 0.053 \\
\hline Acetic/propionic ratio & $1.69^{(\mathrm{a})} \pm 0.010$ & $1.95^{(\mathrm{ab})} \pm 0.013$ & $1.46^{(\mathrm{abc})} \pm 0.010$ & $1.48^{(\mathrm{abd})} \pm 0.015$ & 0.037 \\
\hline
\end{tabular}

Data presented as means $\pm \mathrm{SE}, N=5$

Values having the same letter in the same raw are significantly different at $P<0.05$.

\section{Discussion}

In vitro gas production technique has been proved to be a potentially useful and less expensive technique for feed evaluation in developing countries [27, 31, 32]. To our knowledge this is the first in vitro study conducted to assess the effect of this coupled addition on rumen methane production.

Because several electron acceptors were found successful in diverting $\mathrm{H}_{2}$ away from methanogens (fumarate was the most effective candidate), authors thought that research efforts should be focused on enhancing the activity of fumarate-utilizing bacteria and in this regard defaunation was tested as a tool for potentiating the activity of fumarateutilizing bacteria and enhancing the capacity of ruminal ecosystem to reduce fumarates into propionates.

From the foregoing results it has been observed that coupling defaunation with fumaric acid addition achieved an overwhelming decrease in total gas volume, methane and $\mathrm{CO}_{2}$ production $(32.7 \%, 43.07 \%$, and $40.1 \%$, resp.). The $17.7 \%$ reduction in $\mathrm{CH}_{4}$ production achieved by defaunation could be really attributed to the intimate metabolic correlation existing between methanogenic microorganisms and ciliate protozoa so that defaunation reduced methanogenesis and directed hydrogen for other metabolic processes presumably acetate and propionate production [33, 34], however, the response was lower than that recorded by Ushida et al. [35] and Santra et al. [15]. On the other hand, the $11 \%$ decrease in $\mathrm{CH}_{4}$ production recorded by fumaric acid addition was lower than that recorded by López et al. [13] and Bayaru et al. [14] but was higher than that recorded by Carro and Rannila [36]. These differences could probably be attributed to a diet and dose related factors. It appears that the maximum potential of fumarate to divert $\mathrm{H}_{2}$ away from $\mathrm{CH}_{4}$ is limited presumably because methanogens utilize $\mathrm{H}_{2}$ more rapidly than fumarate-utilizing bacteria. Asanuma et al. [12] suggested that fumarateutilizing bacteria have a disadvantage in the utilization of $\mathrm{H}_{2}$ compared with methanogens when the partial pressure of $\mathrm{H}_{2}$ is low. However, addition of a defaunating agent (SLS) attenuated methanogenic microorganisms and potentiated fumarate utilizing bacteria, making them able to override methanogens and methanogenesis was greatly reduced.

4.1. Effect of Defaunation, Fumaric Acid Addition and SLSFumaric Acid Coupled Addition on Extracellular Cellulase Activity. Because one of the greatest merits of ruminants is the ability to utilize fiber, methane production should be reduced without depressing fiber digestion. Extracellular cellulase activity within the fermentation fluid was not altered by different treatment systems relative to control which indicates efficient $\mathrm{H}_{2}$ disposal without negative drawbacks on cellulolytic bacterial activity. Nevertheless, reduction of substrate degradability by both defaunation and SLSfumaric acid coupled addition may be related to loss of the stabilizing role that protozoa have on the physicochemical characteristics of the ruminal environment [37] and in this regard our results are in accordance with Dohme et al. [38] and Koeing et al. [39].

4.2. Effect of Defaunation, Fumaric Acid Addition and SLSFumaric Acid Coupled, Addition on In Vitro Fermentation Pattern, Microbial Yield and Substrate Degradability. The $\mathrm{pH}$ 
TABLE 4: Effect of treatment systems on extracellular cellulase activity, amount of substrate truly degraded, microbial mass, and biomass yield after 24 hours in vitro incubation.

\begin{tabular}{|c|c|c|c|c|c|}
\hline Parameter & $\begin{array}{l}\text { Control (no } \\
\text { additives) }\end{array}$ & $\begin{array}{l}\text { SLS-addition } \\
\text { (defaunation) }\end{array}$ & $\begin{array}{l}\text { Fumaric acid } \\
\text { addition }\end{array}$ & $\begin{array}{l}\text { SLS-Fumaric } \\
\text { acid coupled } \\
\text { addition }\end{array}$ & L.S.D. \\
\hline $\begin{array}{l}\text { Extracellular cellulase activity ( } \mathrm{mmoL} \\
\text { of glucose equivalent } / \mathrm{min} \text { ) }\end{array}$ & $4.30 \pm 0.11$ & $4.27 \pm 0.07$ & $4.29 \pm 0.05$ & $4.28 \pm 0.07$ & NS \\
\hline $\begin{array}{l}\text { Amount of substrate truly degraded } \\
(\mathrm{mg})\end{array}$ & $78.73^{(\mathrm{a})} \pm 1.33$ & $71.39^{(\mathrm{ab})} \pm 0.66$ & $78.94^{(\mathrm{b})} \pm 1.98$ & $65.63^{(\mathrm{ab})} \pm 0.69$ & 3.853 \\
\hline Microbial mass generated (mg) & $23.51^{(\mathrm{a})} \pm 0.49$ & $26.29^{(\mathrm{ab})} \pm 0.26$ & $23.50^{(\mathrm{b})} \pm 0.75$ & $28.45 \pm 0.26$ & 1.450 \\
\hline $\begin{array}{l}\text { Microbial yield/mmoL ATP generated } \\
\left(\mathrm{Y}_{\text {ATP }}\right)\end{array}$ & $16.80^{(\mathrm{a})} \pm 1.14$ & $22.93^{(\mathrm{ab})} \pm 0.72$ & $16.33^{(\mathrm{b})} \pm 1.52$ & $30.92^{(\mathrm{ab})} \pm 1.32$ & 3.632 \\
\hline
\end{tabular}

Data presented as means $\pm \mathrm{SE}, N=5$

Values having the same letter in the same raw are significantly different at $P<0.05$.

values in the present incubations were much higher than the critical value of 6.0 enabling maximal $\mathrm{CH}_{4}$ formation [40]. The observed increases in propionate production by both fumaric acid addition and SLS-fumaric acid coupled addition could stem from fumarate fermentation itself. The recorded decrease in $\mathrm{CH}_{4}$ corresponded well to the issue that hydrogen diverted away from methane was used to reduce and convert fumarate into propionate with little production of acetate and butyrate. This confirms the possibility that these fumarate-utilizing bacteria compete with methanogens for the utilization of $\mathrm{H}_{2}$. Additionally protozoa ingest both starch grains and amylolytic bacteria associated with them [41]. These amylolytic bacteria are succinate producing and act synergistically with succinate decarboxylating Selenomonas ruminantium to give propionates leading to better energy use since propionate metabolism is more favorable than acetate and butyrate ones [42]. More puzzling is the high yield of acetate at the expense of propionates and butyrates associated with defaunation. The reason for this is not clear but some guesses might be made. First of all, the conversion of glucose to acetate, propionate and butyrate in the rumen results in an overall net release of a reducing power and much of this is used by methanogenic microorganisms to reduce $\mathrm{CO}_{2}$ to $\mathrm{CH}_{4}$, similarly hydrogen can also be used by acetogenic bacteria in reduction of $\mathrm{CO}_{2}$ to acetate (reductive acetogenesis). One of the major constraints to induction of the acetogenic pathway is that the hydrogen threshold for acetogenesis is higher than for methanogenesis as shown by Joblin [43] who concluded that acetogenesis may find its ruminal application when methanogenesis is inhibited. Therefore, high acetate accompanying defaunation in this in vitro study might be the end result of enhanced acetogenesis after suppression of protozoal support to methanogenic microorganisms and/or protozoal predation against fibrolytic bacteria is inhibited by defaunation.

The tendency to lower NH3-N and total SCVFAs concentrations in the fermentation fluid observed by defaunation and coupled addition could be due to a greater utilization by rumen microbes as both microbial mass and microbial yield $\left(\mathrm{Y}_{\text {ATP }}\right)$ were increased in accordance to the decremental effect of each of the previous treatments. Leng [44] and Blümmel et al. [45] hypothesized that an inverse relationship exists between gas or SCVFA production and microbial biomass yield. Additionally the overwhelming microbial cell yield achieved by coupled addition (84\% versus $36.5 \%$ achieved by defaunation) is probably related to the possession of a system for the regeneration of ATP by electron transport phosphorylation coupled with propionate producing bacteria but absent in acetate producing bacteria [46], which implies that these bacteria acquire energy from $\mathrm{H}_{2}$ and which otherwise are used to produce methane as suggested by Asanuma et al. [12]. Furthermore, reduction of methane production by coupled addition $(43.07 \%)$ was more efficient and outperformed methane reduction by defaunation (17.7) and this probably saved more energy as reported by Johnson et al. [47] to meet the synthetic needs of rumen microbes that require a synchronous supply of energy and NH3-N as suggested by Huber and Herrara [48].

In conclusion, sodium lauryl sulfate-fumaric acid coupled addition could achieve an overall complementary effect on reduced methanogenesis which was reflected positively on propionates production, ATP production and microbial mass yield. However, further long-term in vivo studies are required before putting it to practical use.

Conflicts of Interest. The authors declare that there are no conflicts of interest.

Funding. This research received no specific grant from any funding agency in the public, commercial or not-for-profit sectors.

\section{Authors' Contributions}

M. A. Abdl-Rahman and F. A. R. Sawiress designed the study, carried out the sample preparation, reviewed all data, and contributed in the preparation of the manuscript. A. M. Abd El-Aty contributed to the revision and the final form of submission. 


\section{References}

[1] D. E. Johnson, K. A. Johnson, G. M. Ward, and M. E. Branine, "Ruminants and other animals," in Atmospheric Methane: Its Role in the Global Environment, M. A. K. Khalil, Ed., chapter 8, pp. 112-133, Springer, Berlin, Heidelberg, Germany, 2000.

[2] A. R. Moss, J.-P. Jouany, and J. Newbold, "Methane production by ruminants: its contribution to global warming," Animal Research, vol. 49, no. 3, pp. 231-253, 2000.

[3] C. Benchaar, C. Pomar, and J. Chiquette, "Evaluation of dietary strategies to reduce methane production in ruminants: a modelling approach," Canadian Journal of Animal Science, vol. 81, no. 4, pp. 563-574, 2001.

[4] K. A. Beauchemin and S. M. McGinn, "Methane emissions from feedlot cattle fed barley or corn diets," Journal of Animal Science, vol. 83, no. 3, pp. 653-661, 2005.

[5] C. J. Van Nevel and D. I. Demeyer, "Control of rumen methanogenesis," Environmental Monitoring and Assessment, vol. 42, no. 1-2, pp. 73-97, 1996.

[6] M. F. Hutjens, "Selecting feed additives," in Large Dairy Herd Management, H. H. Van Horn and C. J. Wilcox, Eds., pp. 309-317, American Dairy Science Association, Champaign, Ill, USA, 1992.

[7] P. J. Weimer, "Manipulating ruminal fermentation: a microbial ecological perspective," Journal of Animal Science, vol. 76, no. 12, pp. 3114-3122, 1998.

[8] C. J. Newbold, B. Lassalas, and J. P. Jouany, "The importance of methanogens associated with ciliate protozoa in ruminal methane production in vitro," Letters in Applied Microbiology, vol. 21, no. 4, pp. 230-234, 1995.

[9] A. G. Williams, "Rumen holotrich ciliate protozoa," Microbiological Reviews, vol. 50, no. 1, pp. 25-49, 1986.

[10] K. Hillman, D Lloyd, and A. G. William, "Use of protable quadrupole mass spectrometer for the measurement of dissolved gas concentrations in ovine rumen liquor in situ," Current Microbiology, vol. 12, p. 355, 1985.

[11] T. Hino, T. Miwa, H. Saitoh, et al., "Effect of methane production on plant fiber digestion by rumen microorganisms," Bulletin of the Faculty of Agriculture, Meiji University, vol. 106, pp. 27-33, 1995.

[12] N. Asanuma, M. Iwamoto, and T. Hino, "Effect of the addition of fumarate on methane production by ruminal microorganisms in vitro," Journal of Dairy Science, vol. 82, no. 4, pp. 780-787, 1999.

[13] S. López, C. Valdés, C. J. Newbold, and R. J. Wallace, "Influence of sodium fumarate addition on rumen fermentation in vitro," British Journal of Nutrition, vol. 81, no. 1, pp. 59-64, 1999.

[14] E. Bayaru, S. Kanda, T. Kamada, et al., "Effect of fumaric acid on methane production, rumen fermentation, digestibility of cattle fed roughage alone," Journal of Animal Science, vol. 72, pp. 139-146, 2001.

[15] A. Santra, D. N. Kamra, and N. N. Pathak, "Influence of ciliate protozoa on biochemical changes and hydrolytic enzymes in the rumen of Murrah buffalo (Bubalus bubalis)," The Buffalo Journal, vol. 1, pp. 95-100, 1996.

[16] J. B. Russell and J. L. Jeraci, "Effect of carbon monoxide on fermentation of fiber, starch, and amino acids by mixed rumen microorganisms in vitro," Applied and Environmental Microbiology, vol. 48, no. 1, pp. 211-217, 1984.

[17] T. R. Callaway and S. A. Martin, "Effects of cellobiose and monensin on in vitro fermentation of organic acids by mixed ruminal bacteria," Journal of Dairy Science, vol. 80, no. 6, pp. 1126-1135, 1997.
[18] H. K. Goering and P. J. Van Soest, Forage Fiber Analysis. Agricultural Handbook, vol. 379, Agricultural Research Service, US Department of Agriculture, Washington, DC, USA, 1970.

[19] K. H. Menke, L. Raab, A. Salewski, H. Steingass, D. Fritz, and W. Schneider, "The estimation of the digestibility and metabolizable energy content of ruminant feedstuffs from the gas production when they are incubated with rumen liquor in vitro," The Journal of Agricultural Science, vol. 92, pp. 217-222, 1979.

[20] A. Ngamsaeng and M. Wanapat, Evaluation of the effects of local plants by in vitro rumen fermentation and their effects on fermentation end-products, Ph.D. thesis, Department of Animal Science, Kho Kaen University, Khon Kaen, Thailand, 2004.

[21] J. M. Eadie, P. N. Hobson, and S. O. Mann, "A note on some comparisons between the rumen content of barley fed steers and that of young calves also fed on high concentrate rations," Journal of Animal Production, vol. 9, p. 247, 1967.

[22] S. Mathew, S. Sagathevan, J. Thomas, and G. Mathen, "An HPLC method for estimation of volatile fatty acids in ruminal fluid," Indian Journal of Animal Sciences, vol. 67, no. 9, pp. 805807, 1997.

[23] A. L. Chaney and E. P. Marbach, "Modified reagents for determination of urea and ammonia," Clinical Chemistry, vol. 8, pp. 130-132, 1962.

[24] M. J. Wolin, "A Theoretical rumen fermentation balance," Journal of Dairy Science, vol. 43, pp. 1452-1459, 1960.

[25] M. Blümmel, H. Steingass, K. Becker, and H. Soller, "Production of SCFA, $\mathrm{CO}_{2}, \mathrm{CH}_{4}$ and microbial cells in vitro," Proceedings of the Society of Nutrition Physiology, vol. 1, p. 9, 1993.

[26] G. L. Miller, R. Blum, W. E. Glennon, and A. L. Burton, "Measurement of carboxymethylcellulase activity," Analytical Biochemistry, vol. 1, no. 2, pp. 127-132, 1960.

[27] M. Blümmel, H. P. S. Makkar, and K. Becker, "in vitro gas production: a technique revisited," Journal of Animal Physiology and Animal Nutrition, vol. 77, no. 1, pp. 24-34, 1997.

[28] E. E. Grings, M. Blümmel, and K.-H. Südekum, "Methodological considerations in using gas production techniques for estimating ruminal microbial efficiencies for silage-based diets," Animal Feed Science and Technology, vol. 123, pp. 527$545,2005$.

[29] H. R. Isaacson, F. C. Hinds, M. P. Bryant, and F. N. Owens, "Efficiency of energy utilization by mixed rumen bacteria in continuous culture," Journal of Dairy Science, vol. 58, no. 11, pp. 1645-1659, 1975.

[30] G. W. Snedecor and W. G. Cochran, Statistical Methods, Oxford and JBH Publishing, Calcutta, Indian, 7th edition, 1980.

[31] G. Getachew, M. Blümmel, H. P. S. Makkar, and K. Becker, “in vitro gas measuring techniques for assessment of nutritional quality of feeds: a review," Animal Feed Science and Technology, vol. 72, no. 3-4, pp. 261-281, 1998.

[32] M. Herrero, I. Murray, R. H. Fawcett, and J. B. Dent, "Prediction of the in vitro gas production and chemical composition of kikuyu grass by near-infrared reflectance spectroscopy," Animal Feed Science and Technology, vol. 60, no. 1-2, pp. 51-67, 1996.

[33] B. J. Finlay, G. Esteban, K. J. Clarke, A. G. Williams, T. M. Embley, and R. P. Hirt, "Some rumen ciliates have endosymbiotic methanogens," FEMS Microbiology Letters, vol. 117, no. 2, pp. 157-161, 1994. 
[34] C. J. Newbold, B. Lassalas, and J. P. Jouany, “The importance of methanogens associated with ciliate protozoa in ruminal methane production in vitro," Letters in Applied Microbiology, vol. 21, no. 4, pp. 230-234, 1995.

[35] K. Ushida, A. Miyazaki, and R. Kawashima, "Effect of defaunation on ruminal gas and VFA production in vitro," Japanese Journal of Zootechnical Science, pp. 71-77, 1986.

[36] M. D. Carro and M. J. Ranilla, "Effect of the addition of malate on in vitro rumen fermentation of cereal grains," British Journal of Nutrition, vol. 89, no. 2, pp. 181-188, 2003.

[37] A. G. Williams and G. S. Coleman, The Rumen Protozoa, Springer, New York, NY, USA, 1992.

[38] F. Dohme, A. Machmüller, B. L. Estermann, P. Pfister, A. Wasserfallen, and M. Kreuzer, "The role of the rumen ciliate protozoa for methane suppression caused by coconut oil," Letters in Applied Microbiology, vol. 29, no. 3, pp. 187-192, 1999.

[39] K. M. Koenig, C. J. Newbold, F. M. McIntosh, and L. M. Rode, "Effects of protozoa on bacterial nitrogen recycling in the rumen," Journal of Animal Science, vol. 78, no. 9, pp. 2431$2445,2000$.

[40] J. A. S. Van Kessel and J. B. Russell, "The effect of pH on ruminal methanogenesis," FEMS Microbiology Ecology, vol. 20, no. 4, pp. 205-210, 1996.

[41] J. P. Jouany, "Effect of protozoa in plant cell wall and starch digestion in the rumen," in Rumen Microbes and Digestive Physiology in Ruminants, R. Onodera, et al., Ed., pp. 11-24, Japan Science Society Press, Tokyo, Japan, 1997.

[42] M. Eugene, H. Archimede, B. Michalet, and G. Fonty, "Effects of defaunation on microbial activities in the rumen of rams consuming a mixed diet (fresh Digitaria decumbens grass and concentrate)," Animal Research, vol. 53, p. 187, 2004.

[43] K. N. Joblin, "Rumen acetogens and their potential to lower ruminant methane emissions," Australian Journal of Agricultural Research, vol. 50, no. 8, pp. 1307-1313, 1999.

[44] R. A. Leng, "Quantitative ruminant nutrition-a green science," Australian Journal of Agricultural Research, vol. 44, pp. 363-380, 1993.

[45] M. Blümmel, H. Steinga, and K. Becker, "The partitioning of in vitro fermentation products and its bearing for voluntary feed intake," Proceedings of the Society of Nutrition Physiology, vol. 3, p. 123, 1994.

[46] C. S. Stewart and M. P. Bryant, "The rumen bacteria," in The Rumen Microbial Ecosystem, P. N. Hobson, Ed., pp. 21-75, Elsevier Science, New York, NY, USA, 1988.

[47] D. E. Johnson, K. A. Johnson, G. M. Ward, and M. E. Branine, "Ruminants and other animals," in Atmospheric Methane: Its Role in the Global Environment, M. A. K. Khalil, Ed., chapter 8, pp. 112-133, Springer, Berlin, Heidelberg, Germany, 2000.

[48] J. T. Huber and R. Herrara, "Synchrony of protein and energy supply to enhance fermentation," in Principles of Protein Nutrition of Ruminants, J. M. Asplund, Ed., p. 113, CRC, Columbia, SC, USA, 1994. 

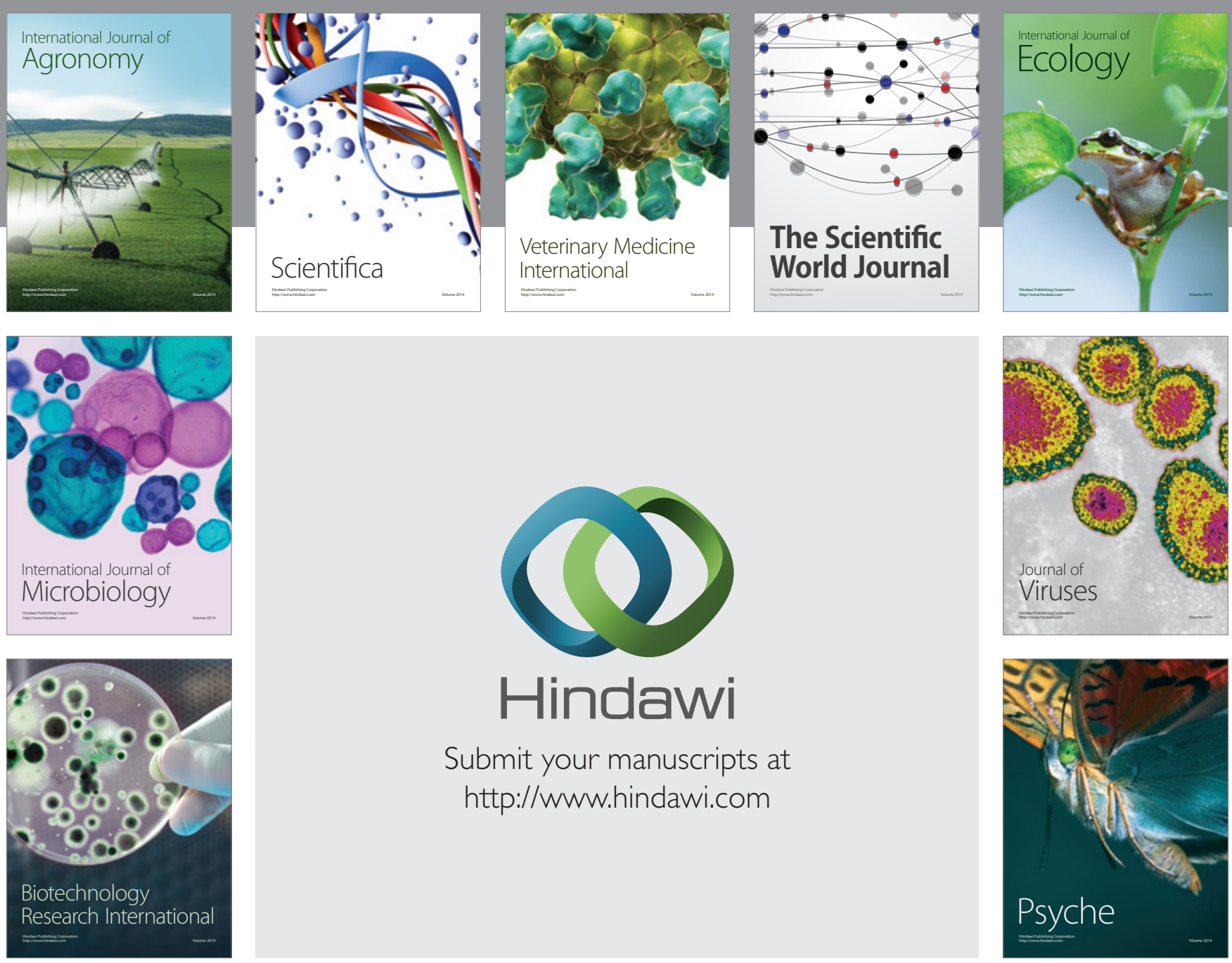

Submit your manuscripts at

http://www.hindawi.com
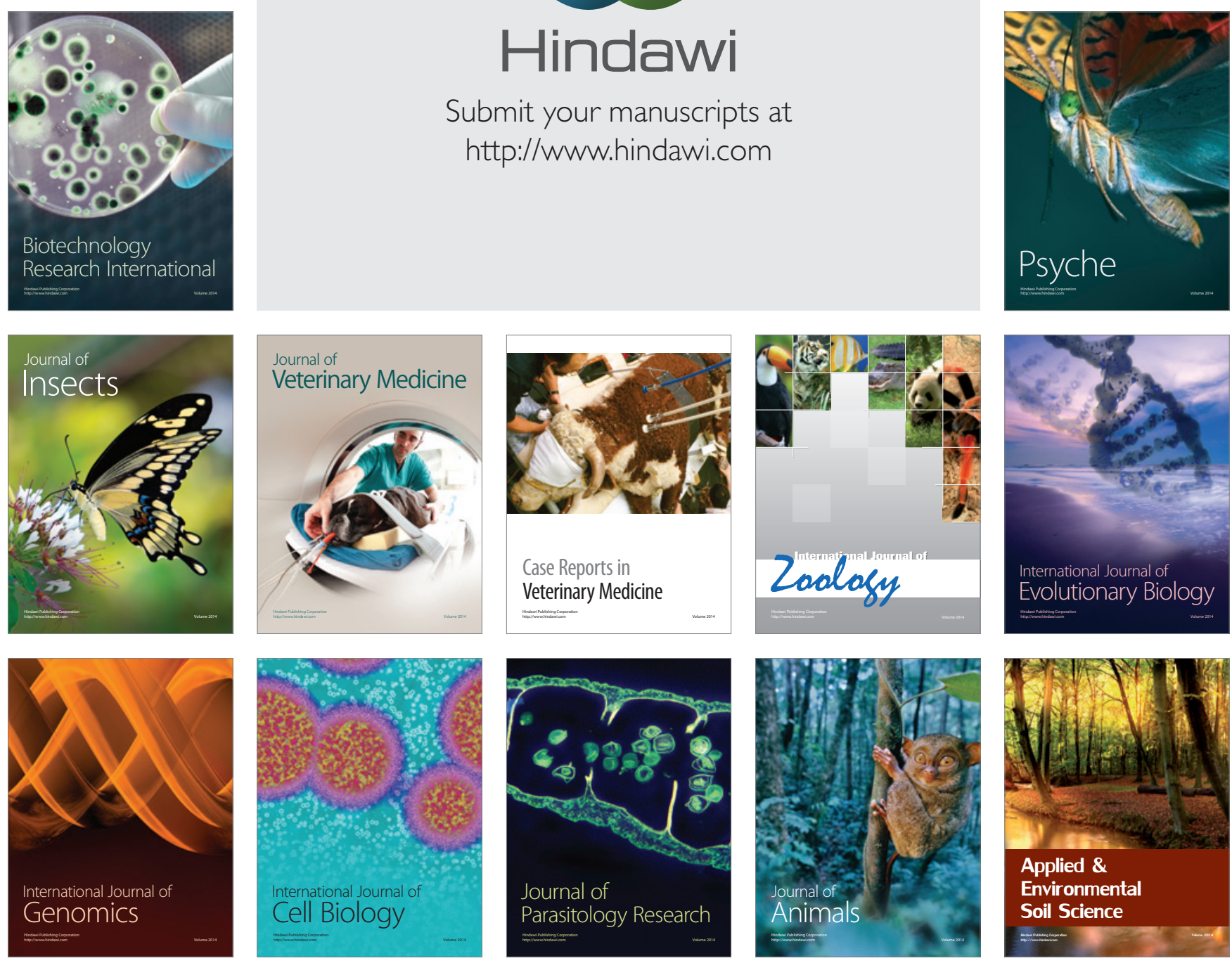